\section{The association between geographical factors and dental caries in a rural area in Mexico}

\author{
Caries dental moderada por variables geográficas \\ espaciales en un medio rural en México
}

\author{
Cárie dentária moderada por variáveis geográficas \\ espaciais em uma área rural do México
}

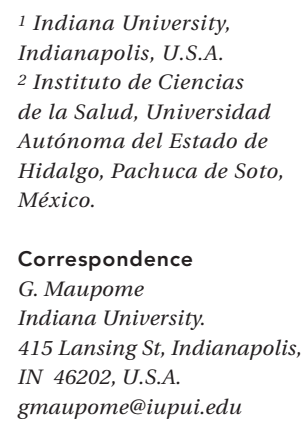

${ }^{1}$ Indiana University, Indianapolis, U.S.A. 2 Instituto de Ciencias de la Salud, Universidad Autónoma del Estado de Hidalgo, Pachuca de Soto, México.

Correspondence G. Maupome Indiana University. 415 Lansing St, Indianapolis, IN 46202, U.S.A. gmaupome@iupui.edu

\begin{abstract}
The aim of this study was to investigate the association between markers of oral disease and geographical factors influencing access to dental care (DMFT score) among school children in Central Mexico. Retrospective data were collected during an international service-learning program between 2002 and 2009. A sample of 1,143 children (55\% females; mean age 12.7 \pm 13.1 years) was analyzed. The mean DMFT score, represented largely by untreated tooth decay, was 4.02 (4.76). The variables that had the most significant effect on the DMFT score were proportion of paved roads between the community and dental services, and the availability of piped potable water. The DMFT score increased in proportion to the percentage of paved roads. In contrast, the DMFT score decreased with the availability of piped potable water. Similar results were found for untreated tooth decay. The main variable associated with a significant increase in dental fillings was proportion of paved roads. Together with Brazilian reports, this is one of the first investigations of the association between geographical factors and oral health in an underdeveloped setting.
\end{abstract}

Oral Health; DMFT Index; Child
Gerardo Maupome 1

E. Angeles Martínez-Mier 1

Alanna Holt 1

Carlo Eduardo Medina-Solís 2

Andrés Mantilla-Rodríguez 1

Brittany Carlton 1

\section{Resumen}

El estudio caracterizó la asociación entre marcadores de salud bucal y de acceso deficiente a servicios dentales con variables geográficas. Se realizó un análisis retrospectivo de datos (recogidos de 2002 a 2009) de 1.143 niños (55\% mujeres;

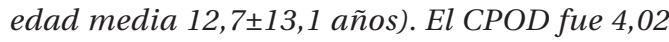
$(4,76)$, constituido primordialmente por caries sin tratar. Las variables con el mayor efecto sobre el CPOD fueron la proporción de caminos pavimentados entre el término municipal principal y comunidades aledañas, y la disponibilidad de agua potable entubada en estas últimas. El CPOD aumentó conforme lo hizo la proporción de los caminos pavimentados. Por el contrario, el CPOD disminuyó moderadamente conforme la disponibilidad de agua potable aumentó. La caries sin tratar exhibió tendencias similares. La única variable fuertemente asociada a un mayor número de tratamientos dentales fue la proporción de caminos pavimentados. Conjuntamente con informes brasileños, este es uno de los primeros estudios sobre la asociación de factores geográficos y salud bucodental en un entorno menos desarrollo.

Salud Bucal; Índice CPO; Niño 


\section{Introduction}

Studies in a number of countries have shown a strong association between poor dental health and low socioeconomic status ${ }^{1}$. In countries that embrace a typical Western diet, characterized by a high intake of simple sugars, the incidence of dental caries (tooth decay) is generally higher among the poorest segments of the population 2 . The fact that dental caries go undetected and untreated for long periods of time in individuals with poor access to dental care is a possible explanation for the higher-than-average experience of tooth decay among these groups. However, why people with low socioeconomic status are more susceptible to poor health is unclear. Possible explanations include the adoption of unhealthy dietary habits and lifestyles by this segment of the population and exposure to a number of factors that undermine health, or a combination of these factors. However, the socioeconomic factors associated with prevalence of dental caries do not fully explain the reason for the caries phenomenon 3 , which may be influenced by social genetic, biological and cultural factors ${ }^{4}$. Tooth decay has been described as a "sentinel disease" for other pediatric conditions 1 , with dental care being the most commonly unmet need 5 .

It has been shown that actions such as reducing the cost of dental care for people with low socioeconomic status ${ }^{6}$, changing the unfavorable mix of dental services 7,8 , or even the provision of free dental care, do not solve the problem of unequal distribution of dental disease or reduce the disparities in access to dental services 9,10. The results of programs directed at reducing cost or access barriers show that these obstacles are merely part of this multidimensional dental health problem 3,11 .

The study of the relationship between geographical location and health has received growing attention in the medical literature and a number of studies in the field of health geography have quantified the association between health and disease characteristics and socioeconomic characteristics 12,13. Factors addressed by health geography studies investigating the dynamics of dental health disparities include the following: the geographical distribution of dental professionals 14,15,16,17; variables representing socioeconomic status 18,19,20,21,22,23; and lifestyle behaviors associated with poor oral health, such as consumption of sugared beverages and dental attendance patterns 16,24 .

However, most studies have been limited to contrasts between rural and urban environments and little research has been carried out into the geographical factors that influence access to dental care and the prevalence of oral conditions $16,20,23,25,26,27,28,29$. Although some Brazilian and Australian studies have investigated geographical barriers 22,23,26,27, we believe that there is still a lack of comprehensive research into these factors. One of the explanations for this gap in research is that most studies in developed nations rightly assume that the distance or time spent traveling to the nearest dental clinic is relatively insignificant compared to the cost of care at the point of delivery; a glaring exception are the long distances involved in visiting the dentist in rural areas in a vast country such as Australia 26,27. Conditions in Latin America, which is not only poorer but has a proportionally smaller dental health network than Australia, are altogether different and prevalence of dental caries in rural areas has not replicated the decisive downward trend experienced in the past couple of decades by industrialized countries. The present study attempts to quantify the association between a limited number of specific geographic factors and the dental health status of children living in a dentally underserved setting.

\section{Methods}

This multiple cross-sectional study adhered to ethical standards and participants signed an informed consent form (Indiana University IRB \# 0202-64).

\section{Description of research location}

Indiana University (IU) implemented an International Service-Learning (ISL) program in the State of Hidalgo in Central Mexico that lasted for over a decade. This program focused activities in the capital city, Pachuca, where an academic partnership was developed with the Universidad Autónoma del Estado de Hidalgo (UAEH), and the municipality of Calnali located in a mountainous area of the Huasteca region.

The municipality of Calnali is made up of a number of small communities and the administration of the municipality and health service policy and management are centralized in the town of Calnali. Public and private medical services are unevenly distributed throughout the municipality and the large majority of dental services are available in Calnali. The State of Hidalgo is one of the states where fluoridated salt is available, which comprises the backbone of the state's dental caries prevention program. Water supplies in Mexico are not artificially fluoridated.

Calnali is more developed (in terms of urban infrastructure, public services and per capita 
income) than the communities. The region is generally mountainous and communities with different population sizes are located at different altitudes and at varying distances and travel times between the community and Calnali. The road network is made up of dirt and paved roads, thus posing different transport challenges. A number of communities lack piped potable water. Although Hidalgo is considered to a very poor state 30 , Western-style snacks and beverages are available throughout the municipality.

Oral diseases are considered public health problems in Mexico, and disproportionately affect the poor and disadvantaged 31,32,33. Dental health care falls within the ambit of the Ministry of Health and only a fraction of dental services are available through the public dental health system, thus most patients seek private dental care and some are forced to forgo dental care.

\section{Data collection}

This is a retrospective analysis of clinical observations from a project that deployed groups of dental, nursing and medical students from IU and UAEH to communities during the ISL program between 2002 and 2009 (Table 1). Elementary school children not using orthodontic appliances that agreed to participate were enrolled in the study after parents signed a written informed consent form. A questionnaire was answered by parents/guardians through a face-to-face interview conducted by bilingual students. Data were collected for different years in different communities due to practical constraints associated with the main objectives of the ISL program which were to provide dental services and raise awareness of the importance of oral health. Although the program prioritized school children, other clients who resided in the community and were seeking care or dental examinations were accepted.

Questionnaires and clinical examinations were carried out during the same visit. Clinical examinations were carried out by standardized dental examiners trained by two calibrated ISL program directors during a semester-long course which included training in data collection, patient data confidentiality, cross-cultural awareness, and standardized diagnostic and management criteria. No formal assessments of intra or inter-examiner reliability were conducted. The present report describes only the status of the crowns of permanent teeth using the DMFT score (decayed, missing due to caries, and filled teeth). Precavitated carious lesions were not scored. The oral examination was conducted under dental lights, using a blunt dental explorer and a flat dental mirror n. 5. Data were not collected for children that were absent on the day of the examination.

\section{Statistical analysis}

DMFT, DT (decayed teeth), and FT scores (filled teeth) were calculated for each individual, and each score was used as a dependent variable. The independent variables were travel distance between Calnali and the community (in kilometers), difference in altitude above sea level between the community and Calnali (in feet), proportion of paved roads between Calnali and the community, travel time between Calnali and the community (in minutes), availability of piped community water supplies, and total population of each community.

Data were analyzed using Poisson and Negative Binomial Regression, since DMFT and its components are not normally distributed and the response variables were counts. Final analysis was carried out using Negative Binomial Regression. Because subjects were grouped into communities and data were grouped into clusters, models were run using generalized estimating equations (GEE negative binomial model) to account for the correlation between study subjects living in the same location 34 . DMFT, DT and FT scores were then compared using incident rate ratios (RR). The RR value can range between 0 and infinity, where $<1$ indicates that the variable has little effect on the score, and > 1 indicates an effect which increases in proportion to the value 35 . Due to the diversity of ages among study subjects, age was considered as the exposure time for each subject within the regressions. A significance level of 0.05 was used.

Data were analyzed using Minitab 16.1.0 (Minitab Inc., State College, USA) and Stata/SE (Stata Corp., College Station, USA).

\section{Results}

The number of subjects, including participants living in Calnali. was 1,366 (Table 1). A total of 223 participants living in Calnali were excluded, giving a final sample of 1,143 (55\% females; overall mean age 12.7 years $(\mathrm{SD}=13.1)$ ). The overall mean DMFT score was 4.02 (4.76). No teeth were recorded as missing due to caries, and untreated decay (D) represented the largest part of the DMFT score. The DMFT score for Calnali was 4.07 (5.03), while the mean DMFT score for surrounding communities was 4.02 (4.76) (Table 1).

Table 2 shows the geographical factors in the ten communities in relation to Calnali. 
Table 1

Mean DMFT scores broken down into the components decayed, missing, and filled teeth for the town of Calnali and communities, State of Hildago, Mexico.

\begin{tabular}{|c|c|c|c|c|c|c|c|c|c|c|c|}
\hline Town & $\mathrm{n}$ & $\begin{array}{c}\text { Mean } \\
\text { age }\end{array}$ & SD & Mean D & SD & Mean M & SD & Mean F & SD & $\begin{array}{l}\text { Mean } \\
\text { DMFT }\end{array}$ & SD \\
\hline Calnali & 223 & 11.60 & \pm 10.80 & 3.01 & \pm 4.43 & 0 & \pm 0 & 1.12 & \pm 2.50 & 4.07 & \pm 5.03 \\
\hline Ahuacatlan & 26 & 22.62 & \pm 20.56 & 8.77 & \pm 5.26 & 0 & \pm 0 & 1.58 & \pm 2.73 & 10.35 & \pm 5.92 \\
\hline Atempa & 73 & 9.08 & \pm 3.48 & 3.13 & \pm 3.53 & 0 & \pm 0 & 0.55 & \pm 1.34 & 3.69 & \pm 3.53 \\
\hline Coamitla & 78 & 10.13 & \pm 3.78 & 2.96 & \pm 3.10 & 0 & \pm 0 & 0.55 & \pm 1.68 & 3.51 & \pm 3.21 \\
\hline Coyula & 207 & 15.93 & \pm 17.63 & 3.257 & \pm 4.90 & 0 & \pm 0 & 0.77 & \pm 2.25 & 4.04 & \pm 5.38 \\
\hline Papatlatla & 196 & 15.26 & \pm 16.09 & 4.34 & \pm 4.16 & 0 & \pm 0 & 0.70 & \pm 2.02 & 5.04 & \pm 4.84 \\
\hline Pezmatlan & 235 & 7.98 & \pm 3.10 & 2.77 & \pm 3.41 & 0.004 & \pm 0.065 & 0.64 & \pm 1.72 & 3.41 & \pm 3.96 \\
\hline San Andres & 195 & 14.56 & \pm 14.55 & 2.90 & \pm 4.72 & 0 & \pm 0 & 0.96 & \pm 2.04 & 3.86 & \pm 5.09 \\
\hline Santa Lucia & 40 & 7.50 & \pm 2.86 & 1.53 & \pm 3.00 & 0 & \pm 0 & 0.98 & \pm 3.38 & 2.50 & \pm 4.74 \\
\hline Techichico & 61 & 15.03 & \pm 13.55 & 0.87 & \pm 1.23 & 0 & \pm 0 & 1.34 & \pm 2.87 & 2.21 & \pm 3.04 \\
\hline Tecpaco & 32 & 9.59 & \pm 2.63 & 5.19 & \pm 5.40 & 0 & \pm 0 & 0.22 & \pm 0.71 & 5.41 & 5.48 \\
\hline Total without Calnali & 1,143 & 12.746 & \pm 13.13 & 3.25 & \pm 4.26 & 0 & \pm 0.029 & 0.78 & \pm 2.07 & 4.02 & \pm 4.76 \\
\hline Total with Calnali & 1,366 & 12.56 & \pm 12.79 & 3.21 & \pm 4.29 & 0 & \pm 0.027 & 0.82 & \pm 2.14 & 4.03 & \pm 4.8 \\
\hline
\end{tabular}

Table 2

Geographical factors in the town of Calnali and communities, State of Hildago, Mexico.

\begin{tabular}{|c|c|c|c|c|c|c|c|c|}
\hline Town & $\mathrm{n}$ & Mean age & SD & $\begin{array}{c}\text { Altitude } \\
\text { difference (ft) }\end{array}$ & $\begin{array}{c}\text { Travel } \\
\text { distance }(\mathrm{km})\end{array}$ & $\begin{array}{c}\text { Paved roads } \\
\text { (\%) }\end{array}$ & $\begin{array}{c}\text { Travel time } \\
\text { (minutes) }\end{array}$ & $\begin{array}{l}\text { Availability of } \\
\text { piped water }\end{array}$ \\
\hline Calnali & 223 & 11.6 & \pm 10.8 & 3,149 & 0 & 100 & 0 & Yes \\
\hline Ahuacatlan & 26 & 22.6 & \pm 20.5 & +735 & 8.1 & 100 & 30 & Yes \\
\hline Atempa & 73 & 9.1 & \pm 3.5 & -295 & 13 & 95 & 40 & Yes \\
\hline Coamitla & 78 & 10.1 & \pm 3.8 & $-2,349$ & 14 & 100 & 40 & Yes \\
\hline Coyula & 207 & 15.9 & \pm 17.6 & -702 & 11.5 & 66 & 40 & Yes \\
\hline Papatlatla & 196 & 15.2 & \pm 16.1 & -570 & 17.1 & 100 & 45 & Yes \\
\hline Pezmatlan & 235 & 7.9 & \pm 3.1 & -557 & 6.9 & 95 & 15 & Yes \\
\hline San Andres & 195 & 14.5 & \pm 14.5 & +676 & 7.5 & 100 & 20 & Yes \\
\hline Santa lucia & 40 & 7.5 & \pm 2.8 & -722 & 15.1 & 70 & 80 & No \\
\hline Techichico & 61 & 15 & \pm 13.5 & -417 & 10.9 & 100 & 15 & No \\
\hline Tecpaco & 32 & 9.6 & \pm 2.6 & +866 & 12 & 50 & 50 & No \\
\hline
\end{tabular}

The variables that had the most significant effect on the DMFT score were proportion of paved roads and availability of piped potable water $[R R=5.02(1.72)$ and $0.36(0.09)$, respectively (Table 3)]. The DMFT score increased in proportion to the increase in proportion of paved roads. In contrast, there was a moderate decrease in the DMFT score with the availability of piped potable water.

The DT score increased significantly with an increase in the proportion of paved roads, and there was a strong decrease in the score with availability of piped potable water. The DT score also decreased slightly with an increase in travel distance between the community and Calnali $[\mathrm{RR}=6.28$ (3.53), 0.18 (0.07), and 0.79 (0.04), respectively (Table 3$)]$.

The variables associated with a significant increase in FT scores were proportion of paved roads and availability of piped potable water $[R R=3.74$ (1.06) and 5.21 (2.16), respectively (Table 3)]. Availability of piped potable water and a larger proportion of paved roads were associated with an increase in the number of filled teeth. 
Results of the general estimating equations (GEE) applied to DMFT scores and two of its components for Calnali town and communities, State of Hildago, Mexico.

\begin{tabular}{|c|c|c|c|c|c|}
\hline Independent variable & Coefficient & $\pm \mathrm{SE}$ & RR & $\pm \mathrm{SE}$ & $95 \% \mathrm{Cl}$ \\
\hline \multicolumn{6}{|l|}{ GEE negative binomial model results for DMFT score } \\
\hline Distance from Calnali & -0.121 & \pm 0.040 & 0.88 & \pm 0.03 & $0.84-0.94$ \\
\hline Altitude difference & 0.000 & \pm 0.000 & 1.00 & \pm 0.00 & $1.00-1.00$ \\
\hline Proportion of paved roads & 1.643 & \pm 0.504 & 5.02 & \pm 1.72 & $2.57-9.83$ \\
\hline Availability of piped water & -0.954 & \pm 0.436 & 0.36 & \pm 0.09 & $0.22-0.60$ \\
\hline Population & 0.000 & \pm 0.000 & 1.00 & \pm 0.00 & $1.00-1.00$ \\
\hline Travel time between community and Calnali & 0.028 & \pm 0.007 & 1.03 & \pm 0.01 & $1.02-1.04$ \\
\hline \multicolumn{6}{|l|}{ GEE negative binomial model results for DT score } \\
\hline Distance from Calnali & -0.23 & \pm 0.044 & 0.79 & \pm 0.04 & $0.72-0.87$ \\
\hline Altitude difference & -0.001 & \pm 0.000 & 1.00 & \pm 0.00 & $1.00-1.00$ \\
\hline Proportion of paved roads & 1.837 & \pm 0.591 & 6.28 & \pm 3.53 & $2.09-18.88$ \\
\hline Availability of piped water & -1.688 & \pm 0.323 & 0.18 & \pm 0.07 & $0.09-0.39$ \\
\hline Population & 0.001 & \pm 0.000 & 1.00 & \pm 0.00 & $1.00-1.00$ \\
\hline Travel time between community and Calnali & 0.039 & \pm 0.009 & 1.04 & \pm 0.01 & $1.02-1.06$ \\
\hline \multicolumn{6}{|l|}{ GEE negative binomial model results for FT score } \\
\hline Distance from Calnali & 0.074 & \pm 0.057 & 1.06 & \pm 0.03 & $1.00-1.12$ \\
\hline Altitude difference & 0.000 & \pm 0.000 & 1.00 & \pm 0.00 & $1.00-1.00$ \\
\hline Proportion of paved roads & 1.388 & \pm 1.249 & 3.74 & \pm 1.06 & $2.15-6.52$ \\
\hline Availability of piped water & 2.030 & \pm 0.778 & 5.22 & \pm 2.16 & $2.31-11.74$ \\
\hline Population & -0.001 & \pm 0.000 & 1.00 & \pm 0.00 & $1.00-1.00$ \\
\hline Travel time between community and Calnali & 0.015 & \pm 0.166 & 1.01 & \pm 0.01 & $0.99-1.02$ \\
\hline
\end{tabular}

DT: decayed teeth; FT: filled teeth; 95\% Cl: 95\% confidence interval.

\section{Discussion}

The present results indicate that even in a largely underserved population there were significant differences in terms of caries experience associated with specific geographical factors. Socioeconomic status and relative household wealth are similar throughout the study area and the standard of living of the region is considered poor by Western standards. The establishment of small locations in mountainous areas in many parts of Latin America have consistently followed a pattern in which those groups lower in the lower socioeconomic status (often of higher Ameridian heritage) are relegated to the least desirable lands, farther away from rivers and flatlands. If the range of socioeconomic status is as narrow as we believe it is, and if the population is ethnically homogeneous (thereby minimizing the role genetic variability plays in caries vulnerability), then it is possible that the observed differences in caries experience are ascribable to greater exposure to decay-inducing agents and/or varied access to dental care. The variables presence of piped potable water and the proportion of paved roads were associated with a significant increase in the filled component of the DMFT score, indicating that when decay is severe enough to require dental fillings, access to Calnali seems to be an important determining factor for experience of restorative dental care.

Higher prevalence of untreated caries was also associated with better roads and shorter travel distance between the community and Calnali, which is the distribution center for Western-type foods and beverages (Table 3), thus suggesting that improved road conditions may facilitate the transport of decay-inducing snacks and beverages to communities. The increased availability of more decaying-inducing snacks and beverages appears to hold a dynamic trade-off with the strong decrease simultaneously seen when community water supplies were available in a given community: the inverse proportions of liquid intake made up by high-calorie, cariogenic beverages and by potable water have been highlighted for Mexico at large 35. Although the rate of consumption of soft drinks in rural areas of the State of Hidalgo is somewhat lower than in urban settings and the more affluent Mexico City 
and Northern border regions 36 , its population nevertheless contributes to the fact that Mexico is second in the world soft drink consumption ranking 37 , and studies shows that the majority of children in the municipality of Calnali consume sugared beverages 38,39 . However, whether better roads are in fact associated with easier access to cariogenic foods and beverages remains uncertain. A separate study of a homogeneously deprived area in Detroit found a strong positive association between caries severity and the proportion of grocery stores 16 , which are sources of cariogenic snacks and beverages, therefore lending credence to the "ease of access" hypothesis.

Travel distance and time between communities and Calnali differed slightly, while variation in altitude was remarkably large for such a small area (Table 1). Easier access due to shorter distances, decreased travel time ${ }^{25}$, and less changes in altitude (i.e.: less steep roads) could theoretically facilitate access to dental services. The FT scores largely reject this hypothesis, while the DT scores show a modest decrease with increasing distances between Calnali and the communities.

The aggregate DMFT scores (missing teeth were almost non-existent) essentially replicated the DT scores.

The findings of the present research should be viewed in the context of the study's strengths and weaknesses to fully understand their significance. This study is a multiple cross-sectional collection of data from a large region in rural Mexico over a nine year period. While training was carried out to standardize data collection, emphasis was given to service delivery. We did not measure exposure of individuals to fluoride; however, fluoride concentrations have been shown to be negligible 39 . Although differences between naturally occurring fluorides in water and fluoridated domestic salt are unlikely, we cannot completely rule out the differential role of fluoride levels in caries prevention across communities. However, this role is unlikely to be significant. Furthermore, it is crucial to resist at- tempts to extrapolate findings to larger populations. Its is not possible to confirm with absolute certainty the association between oral health and the following significant factors: better access to dental care services available in Calnali; greater availability of decay-inducing agents in the communities; availability of potable water (as opposed to bottled beverages); or a combination of these factors. Finally, the temporal ambiguity of cross-sectional designs precludes ascribing cause-effect relationships to variables.

On the other hand the solid modeling approach adopted by this study provided increased knowledge of geographic markers and dental health in rural Latin America and our findings will help guide subsequent studies. The present study adopted a research framework in which data from an area comprising various communities was used to establish whether an association can be made between dental health indicators and a priori geographic markers (travel distance and time between community and dental services, ease of transport and geographic remoteness, and ease of access for transport of decayinducing snacks and drinks to distant communities). We did not specifically investigate possible variations ascribed to nuances in socioeconomic status because data were derived from a generally homogenous, socioeconomically deprived rural location.

In conclusion, our findings suggest a marked association between caries experience (and the treatment of carious lesions) and two markers of a higher degree of urbanization. Further detailed research into the role of these factors in other rural locations and less mountainous areas is necessary to establish whether these variables may be considered potential predictive geographic markers for other areas. Emphasis should be given to the characterization of mechanisms underlying the variables "proportion of paved roads between community and dental services", and "availability of piped community water supplies”. 


\section{Resumo}

O objetivo deste estudo foi investigar a associação entre marcadores de doença bucal e fatores geográficos que influenciam o acesso aos cuidados dentários (índice CPOD) entre crianças escolares na região central do México. Dados retrospectivos foram coletados durante um programa de service-learning internacional entre 2002 e 2009. Uma amostra de 1.143 crianças (55\% meninas;

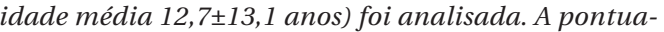
ção média do CPOD, representado em grande parte por cárie não tratada, foi de 4,02 (4,76). As variáveis que tiveram o efeito mais significativo na pontuação do CPOD foram a proporção de estradas pavimentadas entre a comunidade e os serviços odontológicos, e a disponibilidade de água encanada potável. A pontuação do CPOD aumentou em proporção com a quantidade de estradas pavimentadas. Em contraste, o CPOD diminuiu com a disponibilidade de água canalizada potável. Resultados semelhantes foram encontrados para a cárie dentária não tratada. A principal variável associada com um aumento significativo em obturações dentárias foi proporção de estradas pavimentadas. Esta é uma das primeiras investigações sobre a associação entre fatores geográficos e saúde bucal em um ambiente subdesenvolvido.

Saúde Bucal; Índice CPO; Criança

\section{Contributors}

G. Maupome contributed to study design, data analysis and drafting this manuscript. E. Angeles Martínez-Mier, contributed to study design, data collection and drafting this manuscript. A. Holt, Andrés Mantilla-Rodríguez and B. Carlton contributed to the manipulation of data and data analysis and to drafting this manuscript. C. E. Medina-Solís contributed to methodological design, data analysis and interpretation and drafting this manuscript.

\section{Acknowledgments}

The partial support of the Oral Health Research Institute, and the Bi-National/Cross-Cultural Health Enhancement Center of Indiana University, is gratefully acknowledged.

\section{References}

1. Department of Health and Human Services, National Institute of Dental and Craniofacial Research. Oral health in America: a report of the surgeon general. http://silk.nih.gov/public/hck1 ocv.@www.surgeon.fullrpt.pdf (accessed on 30/ Sep/2011).

2. Mueller CD, Schur CL, Paramore, L. Access to dental care in the United States. J Am Dent Assoc 1998; 129:429-37.

3. Boyce WT, Den Besten PK, Stamperdahl J, Zhan L, Jiang Y, Adler NE, et al. Social inequalities in childhood dental caries: the convergent roles of stress, bacteria and disadvantage. Soc Sci Med 2010; 71:1644-52.

4. Evans RG, Stoddart GL. Producing health, consuming health care. In: Evans RG, Barer ML, Marmor TR, editors. Why are some people healthy and others not? The determinants of health of populations. New York: Aldine de Gruyter; 1994. p. 27-64.

5. Waldman H. More children are unable to get dental care than any other single health service. ASDC J Dent Child 1998; 65:204-8.
6. Grembowski D, Andersen R, Chen M. A public health model of the dental care process. Med Care Rev 1989; 46:439-96.

7. Conrad DA, Milgrom P, Kiyak A. Insurance plan effects on dental provider treatment patterns for elderly patients. An experimental economics approach. Med Care 1984; 22:430-46.

8. Bailit HL, Braun R, Maryniuk GA, Camp P. Is periodontal disease the primary cause of tooth extraction in adults? J Am Dent Assoc 1987; 114:40-5.

9. Ismail A, Sohn W. The impact of universal access to dental care on disparities in caries experience in children. J Am Dent Assoc 2001; 132:295-303.

10. Maserejian NN, Tavares MA, Hayes C, Soncini JA, Trachtenberg FL. Rural and urban disparities in caries prevalence in children with unmet dental needs: the New England Children's Amalgam Trial. J Public Health Dent 2008; 68:7-13.

11. Fisher-Owens SA, Gansky SA, Platt LJ, Weintraub JA, Soobader MJ, Bramlett MD, et al. Influences on children's oral health: a conceptual model. Pediatrics 2007; 120:e510-20. 
12. Pabayo R, Belsky J, Gauvin L, Curtis S. Do area characteristics predict change in moderate-tovigorous physical activity from ages 11 to 15 years? Soc Sci Med 2011; 72:430-8.

13. Kawachi I, Berkman LF. Neighborhoods and health. New York: Oxford University Press; 2003.

14. Horner M, Mascarenhas A. Analyzing locationbased accessibility to dental services: an Ohio case study. J Public Health Dent 2007; 67:113-8.

15. Borrell LN, Northridge ME, Miller DB, Golembesk CA, Spielman SE, Sclar ED, et al. Oral health and health care for older adults: a spatial approach for addressing disparities and planning services. Spec Care Dentist 2006; 26:252-6.

16. Tellez M, Sohn W, Burt BA, Ismail AI. Assessment of the relationship between neighborhood characteristics and dental caries severity among lowincome African-Americans: a multilevel approach. J Public Health Dent 2006; 66:30-6.

17. Okunseri C, Szabo A, Garcia RI, Jackson S, Pajewski NM. Provision of fluoride varnish treatment by medical and dental care providers: variation by race/ethnicity and levels of urban influence. J Public Health Dent 2010; 70:211-9.

18. Barbato PR, Nagano HCM, Zanchet FN, Boing AF, Peres MA. Perdas dentárias e fatores sociais, demográficos e de serviços associados em adultos brasileiros: uma análise dos dados do Estudo Epidemiológico Nacional (Projeto SB Brasil 2002 2003). Cad Saúde Pública 2007; 23:1803-14.

19. Matos DL, Lima-Costa MF. Tendência na utilização de serviços odontológicos entre idosos brasileiros e fatores associados: um estudo baseado na Pesquisa Nacional por Amostra de Domicílios (1998 e 2003). Cad Saúde Pública 2007; 23:2740-8.

20. Antunes JL, Peres MA, de Campos Mello TR, Waldman EA. Multilevel assessment of determinants of dental caries experience in Brazil. Community Dent Oral Epidemiol 2006; 34:146-52.

21. Baldani MH, Mendes YB, Lawder JA, de Lara AP, Rodrigues MM, Antunes JL. Inequalities in dental services utilization among Brazilian low-income children: the role of individual determinants. J Public Health Dent 2011; 71:46-53.

22. Moysés ST, Camilotti AG, Vetorello M, Moysés SJ. Spatial analysis of dental trauma in 12-year-old schoolchildren in Curitiba, Brazil. Dent Traumatol 2008; 24:449-53.

23. Pereira SM, Ambrosano GM, Cortellazzi KL, Ta gliaferro EP, Vettorazzi CA, Ferraz SF, et al. Geographic information systems (GIS) in assessing dental health. Int J Environ Res Public Health 2010 7:2423-36.

24. Barriuso-Lapresa L, Sanz-Barbero B. Análisis multinivel del uso de servicios de salud bucodental por población infanto-juvenil. Gac Sanit 2011 25:391-6.

25. Probst JC, Laditka SB, Wang JY, Johnson AO. Effects of residence and race on burden of travel for care cross sectional analysis of the 2001 US National Household Travel Survey. BMC Health Serv Res 2007; 7:40.

26. Australian Research Centre for Population Oral Health. Oral health and access to dental care in Australia - comparisons by cardholder status and geographic region. Aust Dent J 2005; 50:282-5.
27. Curtis B, Evans RW, Sbaraini A, Schwarz E. Geographic location and indirect costs as a barrier to dental treatment: a patient perspective. Aust Dent J 2007; 52:271-5.

28. Adut R, Mann J, Sgan-Cohen HD. Past and present geographic location as oral health markers among older adults. J Public Health Dent 2004; 64:240-3.

29. Levin KA, Davies CA, Douglas GV, Pitts NB. Urbanrural differences in dental caries of 5-year old children in Scotland. Soc Sci Med 2010; 71:2020-7.

30. Consejo Nacional de Evaluación de la Política de Desarrollo Social. II conteo de población y vivienda 2005 y la encuesta nacional de ingresos y gastos de los hogares 2005. http://www.coneval.gob.mx/ cmsconeval/rw/resource/coneval/prensa/959. pdf?view=true (accessed on 07/Sep/2011).

31. Vallejos-Sánchez AA, Medina-Solís CE, MinayaSanchez M, Villalobos-Rodelo JJ, Marquez-Corona $\mathrm{ML}$, Islas $\mathrm{H}$, et al. Maternal characteristics and treatment needs as predictors of dental health services utilisation among Mexican school children. Eur J Paediatr Dent 2012; 13:307-10.

32. Medina-Solís CE, Maupomé G, Ávila-Burgos L, Híjar-Medina M, Segovia-Villanueva A, Pérez-Núñez R. Factors influencing the use of dental health services by preschool children in Mexico. Pediatr Dent 2006; 28:285-92.

33. Medina-Solís CE, Villalobos-Rodelo JJ, MárquezCorona ML, Vallejos-Sánchez AA, Portillo-Núñez CL, Casanova-Rosado AJ. Desigualdades socioeconómicas en la utilización de servicios de salud bucal: estudio en escolares mexicanos de 6 a 12 años de edad. Cad Saúde Pública 2009; 25:2621-31.

34. Sahai H, Khurshid A. Statistics in epidemiology: methods, techniques, and applications. Boca Raton: CRC Press; 1996.

35. Institute of Medicine. Joint US-Mexico Workshop on Preventing Obesity in Children and Youth of Mexican Origin. Washington DC: The National Academies Press; 2007.

36. Barquera S, Campirano F, Bonvecchio A, Hernández-Barrera L, Rivera JA, Popkin BM. Caloric beverage consumption patterns in Mexican children. Nutr J 2010; 9:47.

37. Fomento Económico Mexicano SA. FEMSA 2000 annual report. Monterrey: Fomento Económico Mexicano SA.; 2000.

38. Guido JA, Martinez Mier EA, Soto A, Eggertsson H, Sanders BJ, Jones JE, et al. Caries prevalence and its association with brushing habits, water availability, and the intake of sugared beverages. Int J Paediatr Dent 2011; 21:432-40.

39. Cook SL, Martinez-Mier EA, Dean JA, Weddell JA, Sanders BJ, Eggertsson H, Ofner S, Yoder K. Dental caries experience and association to risk indicators of remote rural populations. Int J Paediatr Dent 2008 Jul; 18:275-83.

40. Batis C, Hernandez-Barrera L, Barquera S, Rivera JA, Popkin BM. Food acculturation drives dietary differences among Mexicans, Mexican Americans, and Non-Hispanic Whites. J Nutr 2011; 141:1898906.

Submitted on 30/Mar/2012

Final version resubmitted 28/Feb/2013

Approved on 04/Mar/2013 